\title{
Zingerone Alleviate Toxicity Induced by Cisplatin or Gamma Radiation in Rats by Modulating Pro-Inflammatory Mediators
}

Gehan R. Abdel-Hamid"1 ${ }^{*}$ Lobna A. Abdel-Aziz ${ }^{2}$, Mona G. Anany ${ }^{3}$

${ }^{1}$ Radiation Biology Department, National Center for Radiation Research and Technology (NCRRT)- Egyptian Atomic Energy Authority (AEA), CairoEgypt.

${ }^{2}$ Health Radiation Research Department, National Center for Radiation Research and Technology (NCRRT)-Atomic Energy Authority (AEA), Cairo. ${ }^{3}$ Faculty of Medicine for Girls, Al-Azhar University, Cairo.

*Corresponding Author: Gehan R. Abdel-Hamid. Radiation Biology Department, National Center for Radiation Research and Technology (NCRRT)-Atomic Energy Authority (AEA), Cairo.

Received Date: October 23, 2021; Accepted Date: October 30, 2021; Published Date: November 05, 2021

Citation: Gehan R. A-Hamid, Lobna A. A-Aziz, Mona G. Anany. (2021). Zingerone Alleviate Toxicity Induced by Cisplatin or Gamma Radiation in Rats by Modulating Pro-Inflammatory Mediators. J. Cancer Research and Cellular Therapeutics. 5(5); DOI: 10.31579/2640-1053/101

Copyright: () 2021 Gehan R. Abdel-Hamid, This is an open-access article distributed under the terms of the Creative Commons Attribution License, which permits unrestricted use, distribution, and reproduction in any medium, provided the original author and source are credited.

\begin{abstract}
Background: Zingerone is one of the active components of ginger that possesses multiple biological activities and anti-inflammatory properties against either radiation effect or cisplatin toxicity.

Purpose: to examine the protective effect of zingerone against gamma radiation (IR) or cisplatin-induced immunotoxicity.

Material and Methods: 48 rats were divided into six groups as follows: (group-1); normal control group received distilled water; (group-2); rats received Zingerone orally at a dose of $25 \mathrm{mg} / \mathrm{kg}$ b.wt. Once / day for 14 consecutive days (Zing.). (group-3); Rats were given a single injection of Cisplatin at a dose of $7.5 \mathrm{mg} / \mathrm{kg} \mathrm{b}$.wt. Intraperitoneally (Cispl.). (group-4); Rats exposed to a single dose of 6 Gy whole-body gamma irradiation using ${ }^{137}$ Cesium source in a Gamma cell 40 (Rad.). (group-5); rats received same dose of Zingerone then they were exposed to gamma radiation as in group 4 (Zing+Rad.). (group-6); rats received Zingerone followed by single injection of Cisplatin at the dose of $7.5 \mathrm{mg} / \mathrm{kg}$ b.wt. Intraperitoneally (Zing+Cisp.).
\end{abstract}

Results: Exhibited a significant increase in expression of NF- $\mathrm{B}$, IL-10, caspase-3, and gene expression of TNF$\alpha$ as well as oxidative stress biomarkers (MDA and NO) levels accompanied with a reduced level of SOD in either whole body-irradiated or cisplatin-received group. Conversely, pro-inflammatory cytokines levels were significantly decreased with an improvement of oxidative stress in groups that received zingerone.

Conclusion: It could be concluded that zingerone exerts its antioxidative activity and immunomodulatory effects through inhibition of pro-inflammatory mediators induced by whole body-gamma irradiation or cisplatin administration at two time interval early and late stage of radiation exposure (after $2 \mathrm{~h}$ and one week). Therefore, further studies are required to elucidate the molecular signaling pathway concerning zingerone.

Keyword: cisplatin; radiation; zingerone; nf- $\kappa b$; tnf- $\alpha$; caspase-3

\section{Introduction}

Although ionizing radiation has a therapeutic effect against solid tumors, it produces oxygen and nitrogen (ROS/RNS) which generate free radicals and produce toxic effects $[1,2]$. In addition, severe complications may result from the combination of it with chemotherapy and it is restricted when large doses are required [3, 4].
Natural products have activities that help to protect against radiation exposure and drugs damage. In addition, they have anti-viral, antiinflammatory, and anti-bacterial properties, as well as cancer prophylaxis [5-8]. Zingerone, an essential oil, extracted from natural product ginger that was reported to have various biological functions including antiapoptotic and antioxidant effects through interfering with the inflammatory pathway leading to a protective effect $[9,10]$. 
Nuclear factor-kappa (NF- $\mathrm{B}$ ) ameliorates the activated B cells and plays an important role in deoxyribonucleic acid (DNA) transcription, cytokine generation and, cell survival. It controls the expression of a large number of genes involved in inflammation such as COX-2, VEGF (vascular endothelial growth Factor) pro-inflammatory cytokines (IL-1, IL-2, IL-6, and $\mathrm{TNF} \alpha$ ), chemokines ( IL-8, MIP-1 $\alpha$, and MCP-1), adhesion molecules, immuno-receptors, growth factors, and other agents involved in proliferation and invasion [11].

Severe oxidative stress resulted from exposure to ionizing radiation that generates a large number of reactive oxygen species (ROS) [12]. Free radical reactions are produced by lipid peroxidation which is a degenerative process that causes damages to the enzyme system and DNA. SOD prevents the formation of a new free radical and converts the existing one into less harmful molecules so participates in deletion and neutralization of toxic ROS. NO is an immune inflammatory factor expressed in response to interferon gamma (IFN- $\gamma$ ) [13-15].

Based on previous studies reported radioprotective effects of ginger essential oil (GEO) on irradiated mice, this study was undertaken to spotlight the activity of zingerone against cisplatin or gamma radiationinduced immunotoxicity and possibilities to be utilized pre- radio and chemotherapy.

\section{Materials and Methods \\ Chemicals}

Zingerone and Cisplatin were obtained from (Sigma- Aldrich Chemical Co., St. Louis, MO, USA). Interleukin-10 (IL-10) (CAT\# ab100764) and tumor necrosis factor- $\alpha$ (TNF- $\alpha)(\mathrm{CAT} \# \underline{\mathrm{ab} 236712)})$. ELISA kits for rat (Abcam Co., Cambridge, MA). SYBR Green Master Mix (Applied Biosystems, Carlsbad, California). NFKB western blot antibody Novus Biologicals, $\beta$-actin was obtained from Santa Cruz Biotechnology (Santa Cruz, California,USA). All the remaining chemicals and reagents were of the highest quality and analytical grade.

\section{Radiation Facility}

Male albino rats were exposed to 6 Gy whole-body gamma irradiation which was performed at NCRRT using Canadian Gamma cell-40 (Cs137), biological irradiator manufactured by Canada Ltd. Ottawa, Ontario, Canada. Animals were placed in a plastic sample tray with lid and supports provided for use in the sample cavity. The unit has ventilation holes which align with ventilation parts through the main shield to provide a means for uniform irradiation for small animals at a dose rate of $0.46 \mathrm{~Gy} / \mathrm{min}$ at the time of experiment according to the guidelines of the Protection and Dosimetry Department.

\section{Animals}

Male Swiss albino rats weighing (120-150 g) used in this study were supplied from the animal breeding house of the National Center for Radiation Research and Technology (NCRRT). Rats were acclimatized in the animal facility of NCRRT for at least one week before subjecting them to experimentation. Rats were kept under standard housing conditions of temperature $\left(22-24{ }^{\circ} \mathrm{C}\right)$ and humidity $(60 \pm 10 \%)$ and a $12 \mathrm{~h} \mathrm{light/} \mathrm{dark}$ cycle. Animals were fed a commercial standard pellet diet (containing necessary nutritive elements $23 \%$ protein, $4.68 \%$ fats and $2.6 \%$ fibers and soya free to minimize natural phytoestrogen supplementation) and water ad libitum during this period.

\section{Experimental design}

48 Male albino rats were maintained under standard environmental conditions, continually monitored for survival and clinical condition till the end of experiment. The study was conducted according to the Ethics Committee of the National Research Centre and in accordance with the recommendations for the proper care and use of laboratory animals (HIN publication No. 85-23, revised 1985). They were divided into six groups as follows: (group-1) (Cont.); normal control group received distilled water. (Group-2) (Zing.); rats received Zingerone (Sigma- Aldrich Chemical Co., St. Louis, MO, USA) orally at a dose of $25 \mathrm{mg} / \mathrm{kg}$ b.wt. Once/ day for 14 consecutive days ${ }^{16}$. (Group-3) (Cispl.); Rats were given a single injection of Cisplatin (Sigma- Aldrich Chemical Co., St. Louis, MO, USA) at a dose of $7.5 \mathrm{mg} / \mathrm{kg}$ b.wt. intraperitoneally. (group-4); rats exposed to a single dose of 6 Gy ${ }^{17}$ whole-body gamma irradiation (Rad.). (Group-5) (Zing+Rad.); rats received Zingerone once/ day for 14 consecutive days then immediately were exposed to gamma radiation (group-6) (Zing+Cisp.); rats received Zingerone once/ day for 14 consecutive days then at the end of Zing treatment followed by single intraperitoneal injection of Cisplatin at the dose of $7.5 \mathrm{mg} / \mathrm{kg} \mathrm{b}$.wt. All animals underwent careful observation along the experimental period. At the end of experiment, (after 2 hours and after one week of radiation exposure, two time intervals) rats were decapitated under gentle diethyl ether anesthesia and then sacrificed. Spleen was excised and collected from animals and stored at $-80^{\circ} \mathrm{C}$.

\section{Determination of the Oxidative Stress in splenic homogenate}

Part of the spleen was weighted and homogenized (10\%) in cold 50 $\mathrm{mmol} / \mathrm{L}$ phosphate-buffered saline, $\mathrm{pH}$ 7.4. The homogenate was centrifuged at $1200 \mathrm{~g}$ for $15 \mathrm{~min}$ at $4{ }^{\circ} \mathrm{C}$, and the supernatant was used. Lipid peroxidation was measured in terms of malondialdehyde (MDA) that measured in spleen according to the method of Yoshioka et al. [18] through thiobarbituric acid assay to forming thiobarbituric acid reactive substances (TBARS). In this reaction one molecule of MDA reacts with two molecules of thiobarbituric acid (TBA) in an acidic medium with production of a pink color of TBA-MDA that is measured at $535 \mathrm{~nm}$.

Nitric oxide (NO) was measured according to the method of [19]. Nitric oxide is relatively unstable in the presence of molecular oxygen, with an apparent half-life of approximately 3-5 sec and is rapidly oxidized to nitrite and nitrate,totally designated as NOx. The assay determines total nitrite/nitrate level based on the reduction of any nitrate level to nitrite by vanadium, followed by the detection of total nitrite (intrinisic + nitrite obtained from reduction of nitrate) by Griess reagent. The Griess reaction entails formation of a chromophore from the diazotization of sulfanilamide by nitrite followed by coupling with bicycle amines, such as N-1-naphthylethylenediamine. The chromophoric a zoderivative can be measured colorimetrically at $540 \mathrm{~nm}$.

Superoxide dismutase activity is measured in tissue homogenate according to the method of Minami and Yoshikawa [20]. Superoxide dismutase (SOD) catalyzes the dismutation of the superoxide radical $\left(\mathrm{O}_{2}-\right.$ ) into hydrogen peroxide $\left(\mathrm{H}_{2} \mathrm{O}_{2}\right)$ and elemental oxygen $\left(\mathrm{O}_{2}\right)$.

$$
\mathrm{O}_{2}^{-}+2 \mathrm{H} \quad \longrightarrow \mathrm{H}_{2} \mathrm{O}_{2}+\mathrm{O}_{2}
$$

Superoxide ions, generated from auto-oxidation of pyrogallol, convert the nitro blue tetrazolium chloride (NBT) to NBT-diformazan which absorbs light at $550 \mathrm{~nm}$. Superoxide dismutase reduces the superoxide ion concentration thereby lowering the rate of NBT-diformazan formation. The extent of reduction in the appearance of NBT-diformazan is a measure of SOD activity present in samples.

\section{Determination of interleukin-10 and tumor necrosis factor- -a assays}

The measurements of Interleukin-10 (IL-10) and tumor necrosis factor- $\alpha$ (TNF- $\alpha$ ) were done, according to the instruction guidelines of the ELISA kits for rat (Abcam Co., Cambridge, MA).

\section{Detection of caspase-3 by quantitative real-time PCR (qRT- PCR)}


Isolation of RNA and Reverse Transcription: Spleen tissue (100 mg) was homogenized in $1 \mathrm{ml}$ TRIzol reagent (Invitrogen, U.S.A.) consequently incubated for $10 \mathrm{~min}$ at room temperature (RT). Samples were mixed with $0.2 \mathrm{ml}$ chloroform and incubated for $3 \mathrm{~min}$ at RT, followed by centrifugation $(12,000 \mathrm{~g}, 15 \mathrm{~min})$. Isopropanol $0.5 \mathrm{ml}$ was added to the isolated aqueous phase, samples were re-centrifuged (12,000 g, $10 \mathrm{~min})$ and the resulting RNA pellet was washed with $75 \%$ ethanol and centrifuged again (7500 g, $5 \mathrm{~min})$. The RNA pellets dissolved in diethylpyrocarbonate (DEPC) water, then incubated $\left(55-60{ }^{\circ} \mathrm{C}, 10 \mathrm{~min}\right)$. Determination of the nucleic acids yield at $260 \mathrm{~nm}$ by a spectrophotometer was done.

The synthesis of cDNA was performed using the Reverse Transcription System (Promega, Leiden, and The Netherlands). Reverse transcription of RNA to synthesize single-stranded complementary DNA (cDNA) was performed using Thermo Scientific ${ }^{\mathrm{TM}}$ RevertAid ${ }^{\mathrm{TM}}$ First Strand cDNA Synthesis Kit (Fermentus, Thermo Fisher Scientific Inc, UK) according to the manufacturer instructions.

\section{Quantitative Real-Time PCR}

qRT-PCR was performed using an optical 96-well plate with an ABI PRISM 7500 fast sequence detection system (Applied Biosystems, Carlsbad, California) using Power SYBR ${ }^{\circledR}$ Green PCR Master Mix (Applied Biosystems, USA.). Syber green (SYBR ${ }^{\circledR}$ Green) chemistry is a method for performing real-time PCR analysis. SYBR ${ }^{\circledR}$ Green dye binds the minor groove of double-stranded DNA. When SYBR ${ }^{\circledR}$ Green dye binds to double-stranded DNA, the intensity of the fluorescence increases. As more double-stranded amplicons are produced, SYBR ${ }^{\circledR}$ Green dye fluorescence increases. The Power SYBR ${ }^{\circledR}$ Green PCR Master Mix can detect as few as 1 to 10 copies of a target gene over a wide range of DNA template concentrations. Universal thermal cycling conditions $\left(95^{\circ} \mathrm{C}\right.$ for $10 \mathrm{~min}, 40$ cycles of $95^{\circ} \mathrm{C}$ for $15 \mathrm{~s}$ and $60^{\circ} \mathrm{C}$ for $60 \mathrm{~s}$ ). Each $10 \mu \mathrm{l}$ reaction contained $5 \mu \mathrm{l} \mathrm{SYBR}$ Green Master Mix (Applied Biosystems), $0.3 \mu 1$ gene-specific forward and reverses primers $(10 \mu \mathrm{M}), 2.5 \mu \mathrm{l}$ cDNA and 1.9 $\mu l$ nuclease-free water.The sequences of PCR primer pairs, (forward 5CAAACCACCAAGTGGAGGAG3,

Reverse3'GTGGGTGAGGAGCACGTAGT-5') and $\beta$-actin (forward 5ATTGTTACCAACTGGGACGACATG-3 Reverse 3'-GAAGTCTA GAGCAACATAGCACA-5) as housekeeping gene. A threshold cycle $(\mathrm{Ct})$ value was used for calculating the fold change expression.

\section{Gel Electrophoresis}

$>\quad$ PCR product $(10 \mu \mathrm{l})$ was analyzed on agarose gel $2 \%$ with ethidium bromide staining, visualized on ultraviolet transilluminator and

semi-quantified by using a gel documentation system (Bio-Doc Analyze, Biometra, Germany). All values were normalized to the $\beta$ actin genes. The relative expression of the RT- PCR amplified products and the fold change in the target genes were determined by the $\Delta \Delta \mathrm{Ct}$ method This method calculates the relative expression rate of the gene of interest by calculating the difference in expression, expressed as cycle threshold $(\mathrm{Ct})$ cycle, between the test gene and the reference gene $(\Delta \mathrm{Ct})$ compared to that of the control samples (calibrator) $(\Delta \Delta \mathrm{Ct})$ then calculating the fold induction using the formula $2^{-(\Delta \Delta \mathrm{Ct})}$.

\section{Western immunoblotting analysis of nuclear factor kappa-} B

Spleen tissue NF- $\kappa$ B protein was extracted using TRIzol reagent and

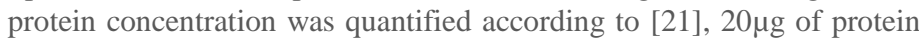
per lane were separated with $10 \%$ SDS-PAGE and transferred onto PVDA membranes. Membranes were incubated at RT for 2 hours with blocking solution (5\% nonfat dried milk in $10 \mathrm{mM}$ TrisCl, pH 7.5, 100 $\mathrm{mM} \mathrm{NaCl}$, and $0.1 \%$ Tween 20), then incubated overnight at $4{ }^{\circ} \mathrm{C}$ with 1:1000 diluted primary antibody towards NF- $\kappa B$ protein with $\beta$-actin as control. After washing 3 times in $10 \mathrm{mM}$ Tris-Cl, pH 7.5, $100 \mathrm{mM} \mathrm{NaCl}$, and $0.1 \%$ Tween 20 , the membrane was incubated with the secondary monoclonal antibody (Cell Signaling Technologies, USA) conjugated to horseradish peroxidase at RT for $2 \mathrm{~h}$, and then membranes were washed 4 times with the same washing buffer. The membrane was developed and visualized by chemiluminescence. The NF- $\kappa$ B protein was quantified by scanning a laser densitometer (Biomed Instrument Inc., USA).

\section{Statistical analysis}

Data analyses were performed using the SPSS 23.0 software (SPSS Inc., Chicago, IL, USA). All analyses were used One-way ANOVA, all experimental values were shown the mean \pm SD. $p \leq 0.05$ was considered significant for all tests.

\section{Results}

The data presented in Table (1) showed that exposure to 6 Gy $\gamma$-radiations or injection with cisplatin resulted in a significant elevation at $p \leq 0.05$ in lipid peroxidation (MDA) levels and nitric oxide accompanied with a reduced level of SOD at all the time intervals examined compared to control group. Meanwhile, pre-administration of Zingerone attenuated and decreased the elevated levels of the oxidative stress markers (MDA and NO) along with enhancement in the SOD activity.

\begin{tabular}{|c|c|c|c|}
\hline Groups & $\begin{array}{c}\text { NO } \\
(\mu \mathrm{mol} / \mathrm{g} \text { wet }) \text { tissue }\end{array}$ & $\begin{array}{c}\text { SOD } \\
(\mathrm{U} / \mathrm{g} \text { wet tissue })\end{array}$ & $\begin{array}{c}\text { MDA } \\
(\mathrm{nmol} / \mathrm{g} \text { wet tissue })\end{array}$ \\
\hline Control & $2.15 \pm 0.2$ & $3.64 \pm 0.1$ & $1.76 \pm 0.1$ \\
2h 1week & $1.40 \pm 0.2$ & $3.96 \pm 0.1$ & $1.67 \pm 0.1$ \\
\hline Zin. & $2.35 \pm 0.1$ & $3.64 \pm 0.2$ & $1.96 \pm 0.1$ \\
2h 1week & $1.34 \pm 0.2$ & $4.38 \pm 0.2^{\mathrm{a}}$ & $0.98 \pm 0.01$ \\
\hline Cispl. & $13.98 \pm 0.1^{\mathrm{ab}}$ & $0.64 \pm 0.1^{\mathrm{ab}}$ & $21.64 \pm 2.2^{\mathrm{ab}}$ \\
\hline 2h 1week & $18.96 \pm 0.8^{\mathrm{ab}}$ & $0.36 \pm 0.04^{\mathrm{ab}}$ & $54.36 \pm 4.4^{\mathrm{ab}}$ \\
\hline Rad. & $21.18 \pm 0.1^{\mathrm{ab}}$ & $0.95 \pm 0.01^{\mathrm{ab}}$ & $18.04 \pm 0.6^{\mathrm{ab}}$ \\
\hline 2h 1week & $31.8 \pm 0.9^{\mathrm{ab}}$ & $0.74 \pm 0.03^{\mathrm{ab}}$ & $54.69 \pm 5.6^{\mathrm{ab}}$ \\
\hline Zin+Rad. & $11.83 \pm 0.4^{\mathrm{a}}$ & $1.58 \pm 0.1^{\mathrm{a}}$ & $8.36 \pm 0.1$ \\
\hline 2h 1Week & $14.72 \pm 0.8^{\mathrm{a}}$ & $1.90 \pm 0.1^{\mathrm{a}}$ & $16.86 \pm 1.5^{\mathrm{a}}$ \\
\hline Zin+Cis. & $7 \pm 0.03^{\mathrm{ac}}$ & $1.4 \pm 0.2^{\mathrm{ac}}$ & $7.65 \pm 0.2^{\mathrm{c}}$ \\
\hline 2h 1week & $9.50 \pm 0.3^{\mathrm{ac}}$ & $1.78 \pm 0.1^{\mathrm{ac}}$ & $21.85 \pm 2.9^{\mathrm{ac}}$ \\
\hline
\end{tabular}

Table 1: Effect of oral administration of zingerone on oxidative stress/ antioxidant Markers

All values are expressed as means \pm SD. a Significant difference vs. control group at $\mathrm{p} \leq 0.05$. $\mathrm{b}$ significant difference vs. zingerone group at $\mathrm{p} \leq 0.05$. c Significant difference vs. Cisplatin group at $\mathrm{p} \leq 0.05$. $\mathrm{d}$ Significant difference vs. Rad. group at $\mathrm{p} \leq 0.05$
The obtained data in Fig. 1 revealed a significant increment at $p \leq 0.05$ in the pro-inflammatory mediator TNF- $\alpha$, accompanied by a significant decrease in anti-inflammatory cytokine IL-10 in both cisplatin and gamma-irradiated groups at the two-time intervals compared to the 
control group. On the other hand, the administration of zingerone has an opposing effect throughout modulating the pro-inflammatory/ antiinflammatory mediator.
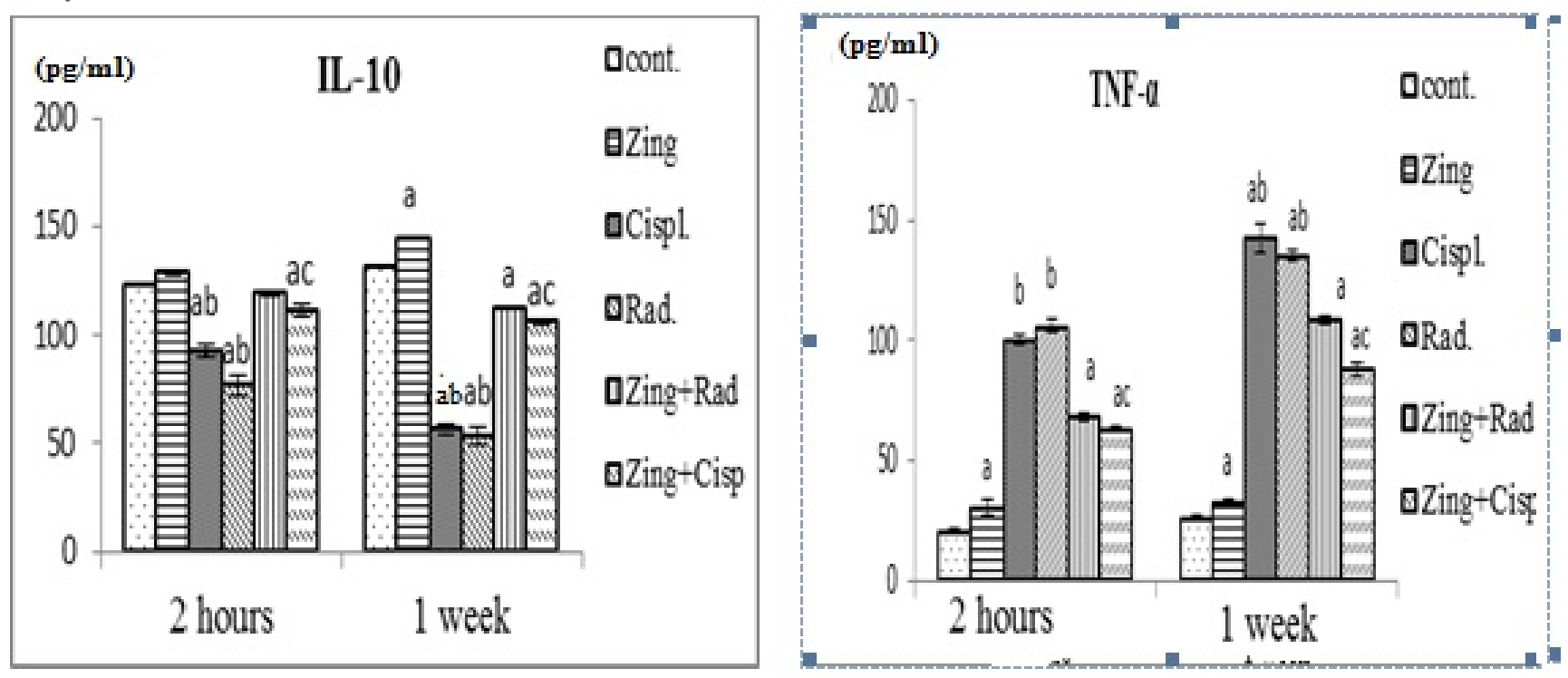

Figure 1: Effect of oral administration of zingerone on inflammatory mediators. All values are expressed as means \pm SD. a Significant difference vs. control group. b significant difference vs. zingerone group. c Significant difference vs. Cisplatin group. d Significant difference vs. Rad. group $(p \leq 0.05)$.

As shown in Fig. 2, overexpression of caspase-3 in the spleen tissues of rats injected with cisplatin or exposed to gamma radiation at the two-time intervals was detected compared to normal control group. Conversely, treatment with zingerone resulted in a significant decline at $\mathrm{p} \leq 0.05$ in its expression which may be due to the anti-apoptotic effect.

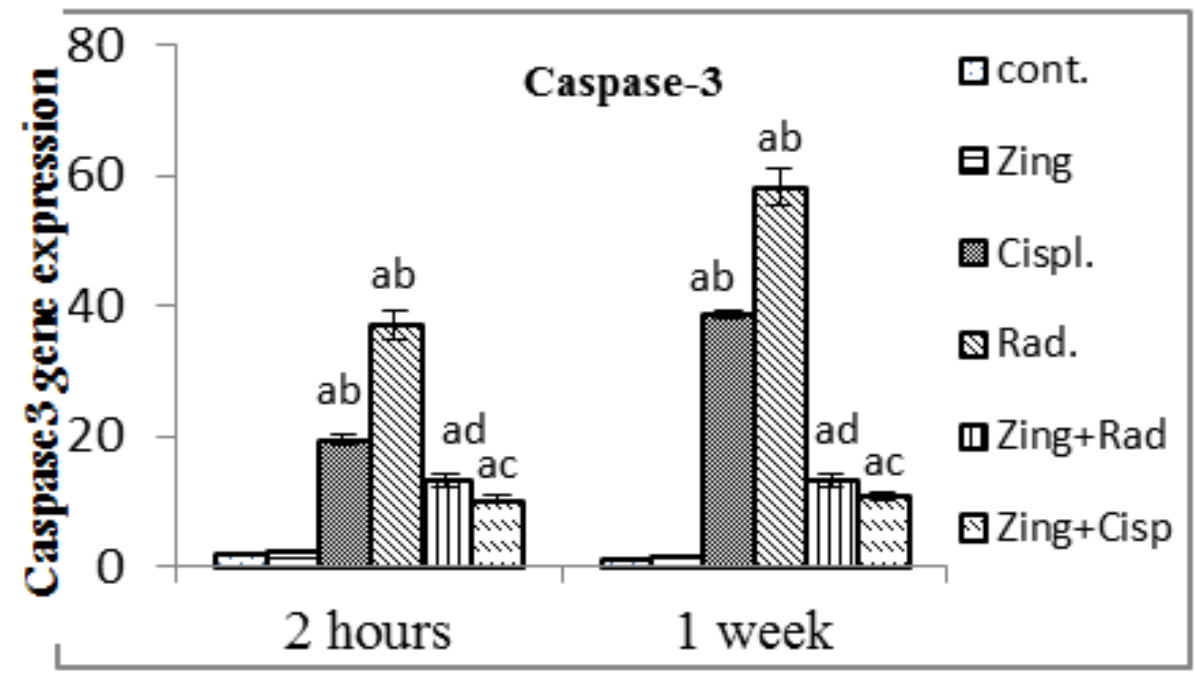

Figure 2: Effect of oral administration of zingerone on caspase-3 expression.

All values are expressed as means \pm SD. a: Significant difference vs. control group. b: significant difference vs. zingerone group. c: Significant difference vs. cisplatin group. d: Significant difference vs. Rad. group $(p \leq 0.05)$

$\mathrm{NF}-\kappa \mathrm{B}$ activation is required for pro-inflammatory responses and the most important providers of inflammatory molecules are NF- $\kappa \mathrm{B}$ and TNF- $\alpha$. The experimental data (Fig. 3) showed that cisplatin or gamma-irradiation induced markedly upregulation of $\mathrm{NF}-\mathrm{\kappa B}$ protein expression in comparison with the control group at the two-time intervals. In contrast, the administration of zingerone was significantly downregulated its expression at $\mathrm{p} \leq 0.05$. 

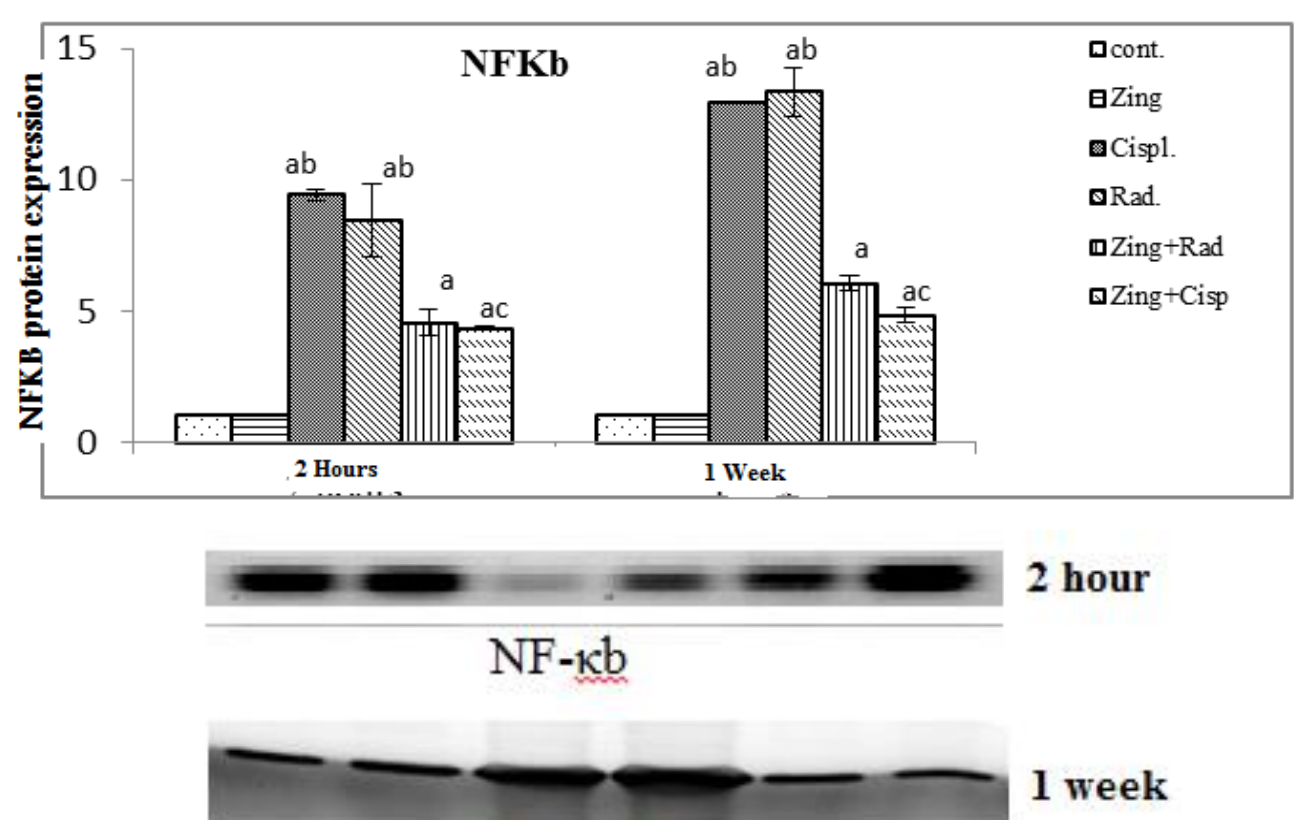

Beta actin

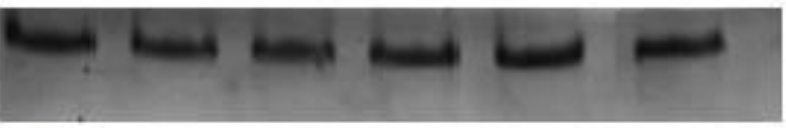

control : Zinger Cisplatin Rad Cis +Zing Rad +Zing

\begin{abstract}
Figure 3. Effect of oral administration of zingerone on $N F-\kappa B$ protein expression at the two-time intervals. All values are expressed as means $\pm S D$. a Significant difference vs. control group. b significant difference vs. zingerone group. C Significant difference vs. cisplatin group. $d$ Significant difference vs. Rad. group ( $p \leq 0.05)$.
\end{abstract}

\section{Discussion}

Exposure to ionizing radiation (IR) has occurred during radiology (diagnostic or interventional), radiotherapy and occupational exposure in the radiation field. High radiation doses cause death whereas sublethal doses may induce diverse diseases, such as cancer, cardiovas cular diseases and cataracts [22]. In addition, ionizing radiation may cause harm to normal tissue with many complications that affect biological and physiological systems so they should be protected [23, 24].

The immune response in the damaged tissues as a result of radiation and chemotherapy is mediated by inflammatory cytokines response (polypeptide). The present investigations showed a significant elevation of the pro-inflammatory mediators TNF- $\alpha, \mathrm{NF}-\kappa \beta$ and caspase 3 accompanied by a significant reduction of anti-inflammatory cytokine (IL-10) after treatment with cisplatin or radiation exposure. These results coincide with the findings of [25]. Who suggested that enhanced inflammation by cisplatin may induce apoptosis by promoting caspase 3 activation and increased TNF- $\alpha$ and IFN- $\gamma$ levels with decreased IL-10 release.

In the current study, prophylactic treatment of zingerone revealed an amelioration of the inflammatory responses caused by cisplatin with significantly decreased expression of both NFאB and TNF- $\alpha$. In agreement with our study, previous reports suggested the zingerone inhibits colitis in rats by downregulating NF-kB activity, MAPK and IL10 signaling pathways $[26,27]$. It was found to suppress the activity of both PPAR, and NF-kB [28].
Data of the present study, revealed high levels of MDA and NO accompanied by remarkable decreases of SOD, compared to the control status, reflecting the cisplatin toxicity, represented by depletion of the antioxidant system [29], and it has been supposed that cisplatin generates free radicals by interacting with DNA. In agreement with this, previous studies reported that $\mathrm{NF} \kappa \mathrm{B}$ activation is crucial in the expression of proinflammatory cytokines like TNF- $\alpha$ and other conditions related to increased ROS generation. In addition, Genetic generation of potentially cell-damaging oxidative enzymes like NADP oxidase and iNOS is induced due to the stimulation of transcription factor NF- $\kappa$ B by TNF- $\alpha$. Inhibitors of $\mathrm{NF} \kappa \mathrm{B}$ have shown to protects against cisplatin-induced toxicity [30-32].

Administration of zingerone before cisplatin treatment also attenuates damage induced by cisplatin treatment; a decrease of malondialdehyde with concurrent amelioration of antioxidant activities was remarkable by its protective effect [33-36]. This protective effect against cisplatininduced toxicity probably might be through the attenuation of oxidative stress and inflammation. Besides, that it aids in maintaining antioxidant and suppresses activation of redox-active transcription factor NFאB [10].

Pretreatment of whole body radiation-exposure group with ginger showed significant improvement of oxidative stress. This coincided with the study of [24] reported that radiation induced reduction in intestinal tissue antioxidant enzyme levels such as superoxide dismutase, catalase, glutathione peroxidase, and glutathione which was reversed following administration of ginger essential oil. 


\section{Conclusion}

As mentioned, it can be concluded that zingerone has an ameliorative effect against oxidative stress induced by cisplatin or gamma radiation by modulating the inflammatory process and targeting the NF-kB pathway. Therefore, it is recommended to use zingerone as an adjuvant therapy to reduce the toxicity resulting from radiotherapy or chemotherapy. More investigations are required to know the exact mechanistic pathway.

\section{Acknowledgments}

Thanks to all the authors.

\section{Conflicting Interests}

The author(s) declared no potential conflicts of interest with respect to the research, authorship, and/or publication of this article.

\section{References}

1. Ismail A, El-Sonbaty S. (2016). Fermentation enhances Ginkgo biloba protective role on gamma-irradiation induced neuro inflammatory gene expression and stress hormones in rat brain. J Photo chem Photobiol B Biol. 158: 154-163.

2. Nabeel A, Moawed F, Hassan H. (2018). Immunomodulatory. Effect of new quinolone derivative against cisplatin/gamma radiation-induced renal and brain toxicity in mice, J Photochem Photobiol. 184:54-60.

3. Kinsella T. (2011). Radiation oncology: today and tomorrow, Front. Oncol. 11-12.

4. Silasi G, Diaz-Heijtz R, Besplug J, et al. (2004). Selective brain responses to acute and chronic low-dose X-ray irradiation in males and females, Biochem Biophys Res Commun. 325: 12231235.

5. Edris A. (2007). Pharmaceutical and therapeutic potential of essential oils and their individual volatile constituents. Phytother Res. 21: 308-323.

6. Mello G, Grespan R, Fonseca J, et al. (2011). Inhibitory effects of ginger (Zingiber officinale Roscoe) essential oil on leukocyte migration in vivo and in vitro, J Nat Med. 65: 241-246.

7. Kumar L, Chhibber S, Harjai K. (2014). Hepato protective effect of zingerone (4-(4 hydroxy-3-methoxyphenyl) butan-2One) in lipopolysaccharide induced liver injury mouse model through down regulation of inflammatory mediators, Int J Pharmacogn Phytochem Res. 6: 308-314.

8. Xie X, Sun S, Zhong W, et al. (2014). Zingerone attenuates lipo polysaccharide induced acute lung injury in mice, Int Immuno pharmacol. 19:103-109.

9. Alibakhshi T, Khodayar MJ, Khorsandi L, et al. (2018). Protective effects of zingerone on oxidative stress and inflammation in cisplatin-induced rat nephrotoxicity. Biomed Pharmacother. 105: 225-232.10.

10. Muneeb U, Ahmad B, Arif A, et al. Zingerone protects against cisplatin-induced oxidative damage in the jejunum Wistar rats, Orient Pharm Exp Med. 15(3):1-8.

11. Yahfoufi N, Alsadi N, Jambi M, et al. (2018). AntiInflammatory Role of Polyphenols. Nutrients. 10 (11): 1618.

12. Xue XL, Xiao-Lei, Han XD, et al. (2017). Astaxanthin attenuates total body irradiation-induced hematopoietic system injury in mice via inhibition of oxidative stress and apoptosis. Stem Cell Research \& Therapy. 8:7.

13. Almeer RS, Alarifi S, Alkahtani S, et al. (2018). The potential hepatoprotective effect of royal jelly against cadmium chlorideinduced hepatotoxicity in mice is mediated by suppression of oxidative stress and upregulation of Nrf2 expression. Biomed Pharmacother. 106: 1490-1498.
14. Saada HN, Azab KS. (2014). Role of lycopene in recovery of radiation induced injury to mammalian cellular organelles. Pharmazie. 56: 239-241.

15. Yarovinsky F. (2014). Innate immunity to Toxoplasma gondii infection. Nat Rev Immunol. 14:109-121.

16. Rehman M, Tahir M, Khan A, et al. (2014). D-limonene suppresses doxorubicin induced oxidative stress and inflammation via repression of COX-2, iNOS, and NFKB in kidneys of Wistar rats, Exp Biol Med. 239 (4): 465-476.

17. Mansour HH. (2006). Protective role of carnitine ester against radiation-induced oxidative stress in rats. Pharmacol Res. 54(3):165-171.

18. Yoshioka T, Kawada K, Shimada T, Mori M. (1979). Lipid peroxidation in maternal and cord blood and protective mechanism against activated-oxygen toxicity in the blood, Am.J. Obstet. Gynecol. 135(3): 372.

19. Miranda KM, Espey MG and Wink DA. (2001). A rapid simple spectro photometric method for simultaneous detection of nitrate and nitrite. Nitric Oxide. 5: 62-71.

20. Nishikimi M, Roa N, Yogi K. (1972). The occurrence of superoxide anion in the reaction of reduced phenazine metho sulfate and molecular oxygen. Biochem Biophys Res Commun. 46: 849-854

21. Bradford M. (1976). Rapid and sensitive method for the quantitation of microgram quantities of protein utilizing the principle of protein-dye binding. Anal Biochem. 72: 248-254.

22. El Bakary NM, Thabet NM, El Fatih NM et al. (2021). Fucoxanthin alters the apelin-13/APJ pathway in certain organs of $\gamma$-irradiated mice. Journal of Radiation Research. 1-18.

23. Guo J, Cai J, Zhang Y, et al. (2017). Establishment of two ovarian cancer orthotopicxenograft mouse models for in vivo imaging: A comparative study. Int J Oncol. 51(4): 1199-1208.

24. Wu J, Duan Y, Cui1J, et al. (2019). Protective effects of zingerone derivate on ionizing radiation-induced intestinal injury. Journal of Radiation Research. 60(6): 740-746.

25. Myung S, Kim Y, Ju W, et al. (2010). Effects of antioxidant supplements on cancer prevention: meta-analysis of randomized controlled trials, Annals of Oncology. 21:166-179.

26. Hsiang C, Lo H, Huang H, et al. (2013). Ginger extract and zingerone ameliorated tri nitrobenzene sulphonic acid-induced colitis in mice via modulation of nuclear factor-kB activity and interleukin-1 $\beta$ signaling pathway. Food Chemistry. 136(1): 70177.

27. Kim M, Yang H, Kim H, et al. (2010). IL-10 Mediates Rosiglitazone-Induced Kidney Protection in Cisplatin Nephrotoxicity, J Korean Med Sci. 25: 557-563.

28. Chung J, Kim D, Choi J, et al. (2009). Peroxisome proliferator activated receptor activation by a short term feeding of zingerone in aged rats. J Med Food. 12: 345-350.

29. Masuda H, Tanaka T, Takahama U. (1994). Cisplatin generates superoxide anion by interaction with DNA in a cell-free system, Biochem Biophys Res Commun. 203: 1175-1180.

30. Francescato H, Costa $\mathrm{H}$ et al. (2007). Parthenolide reduces cisplatin induced renal damage. Toxicology. 230: 64-75.

31. Nanji A, Jokelainen K et al. (2003). Curcumin prevents alcoholinduced liver disease in rats by inhibiting the expression of NFkappa B dependent, Am J Physiol Gastrointest Liver Physiol. 284 (2): 321-327.

32. Ramesh G, Reeves W. (2002). TNFR2-mediated apoptosis and necrosis in cisplatin induced acute renal failure, Am J Physiol Renal Physio. 285: 610-618.

33. Kamtchouing P, Fandio G, Dimo T, et al. (2013). Evaluation of angrogenic activity of Zingiber officinale and pentadiplandra 
brazzeana in male rats, Asian J Androl 2002; 4 299-301. Pharmacol Biochem Behav. 113: 53-62.

34. Zancan K, Marques M, Petenate A, et al. (2002). Extraction of ginger (Zingiber officinal Roscoe) oleoresin with $\mathrm{CO} 2$ and cosolvents: a study of the antioxidant action of the extracts, J Supercrit Flu. 24: 57-76.
35. Jeena MT, Palanikumar L, Go EM, et al. (2017). Mitochondria localization induced self-assembly of peptide amphiphiles for cellular dysfunction. Nature Communications. 8(1).

36. Hasan HF, Rashed LA, El Bakary NM. (2021). Concerted outcome of metformin and low dose of radiation in modulation of cisplatin induced uremic encephalopathy via renal and neural preservation.Life Sciences. 276.
This work is licensed under Creative Commons Attribution 4.0 License

To Submit Your Article Click Here: Submit Manuscript

DOI: $10.31579 / 2640-1053 / 101$
Ready to submit your research? Choose Auctores and benefit from:

$>$ fast, convenient online submission

$>$ rigorous peer review by experienced research in your field

$>$ rapid publication on acceptance

$>$ authors retain copyrights

$>$ unique DOI for all articles

$>$ immediate, unrestricted online access

At Auctores, research is always in progress.

Learn more auctoresonline.org/journals/cancer-research-and-cellulartherapeutics 